Kong. Res. J. 2(1) : 24-28-, 2015

ISSN 2349-2694

Kongunadu Arts and Science College, Coimbatore.

\title{
SYNTHESIS, CHARACTERIZATION, DNA BINDING AND ANTIBACTERIAL ACTIVITY OF RUTHENIUM(III) COMPLEX CONTAINING MIXED LIGANDS
}

\author{
Sampath ${ }^{1} \mathrm{~K}$. and C. Jayabalakrishnan ${ }^{2 *}$ \\ ${ }^{1}$ Department of Chemistry, Kumaraguru College of Technology, Coimbatore - 641 006, Tamil Nadu, India. \\ 2P.G \& Research Department of Chemistry, Sri Ramakrishna Mission Vidyalaya College of Arts and Science, \\ Coimbatore-641020. \\ *Email-drcjbstar@gmail.com
}

\begin{abstract}
Ruthenium(III) complex, $\left[\mathrm{RuBr}_{2}\left(\mathrm{AsPh}_{3}\right)_{2} \mathrm{~L}\right]$ (where $\mathrm{L}=$ (E)-2-(2-chlorobenzylidene)-Nmethylhydrazinecarbothioamide) have been synthesized. Structural features of the complex were determined by various physico-chemical and spectral techniques. DNA binding of the complex was investigated by absorption spectroscopy which indicated that the complex bind to DNA via intercalation and this complex bind strongly than ligand. The complex has shown significant growth inhibition activity against a panel of bacteria which indicating the pharmacological significance of the ruthenium(III) complex.
\end{abstract}

Keywords: Ruthenium(III) complexes, Thiosemicarbazones, DNA binding, Cytotoxicity.

\section{INTRODUCTION}

Though possible remedial measures are available at present to tackle any disease, continuous search in trying to find better and more effective drugs is on the increase. This is particularly true in the case of cancer where cisplatin and its analogs such as carboplatin, and oxaliplatin during chemotherapy result in drawbacks, including intrinsic or acquired resistance, and toxicity. So, the efforts to mitigate the drawbacks have prompted chemists to synthesize a variety of analogs, which is valuable not only for providing better drugs but also for offering useful tools in the study of the molecular mechanisms underlying tumor development. In this connection, ruthenium based complexes have shown enormous impact. Though a wide range of ruthenium complexes have been described in the literature, only a few of them show outstanding anticancer activity (Yan et al., 2005; Ang and Dyson, 2006; Ronconi and Sadler, 2007) and two of them, for instance NAMI-A and KP1019, are currently involved in clinical trials (Rademaker-Lakhai et al., 2004; Hartinger et al., 2006; Kostova, 2006). A combination of such ruthenium with the potent cytotoxic thiosemicarbazone pharmacophore has been shown to produce synergistic effects on the antiproliferative activity of the parent steroidal ligands (Murugkar et al., 1999). The above discussions have inspired us to synthesize a new ruthenium complex containing thiosemicarbazone ligand and triphenylarsine, and bromine as ancillary ligands. The biological properties of the complex were investigated by interaction with DNA. DNA is considered to be one of the major pharmacological targets of anticancer drugs because metal complexes exert their anticancer effects through binding to DNA, thereby changing the replication of DNA and inhibiting the growth of the tumor cells (Pyle et al., 1990; Friedaman et al., 1991). So the objective of the present work is to understand in detail the interaction of the new complexes with DNA. Further, the in vitro cytotoxicity of the synthesized complex was also been determined.

\section{EXPERIMENTAL}

\subsection{Materials and methods}

All the chemicals used were chemically pure and AR grade. Solvents were purified and dried according to the standard procedure (Vogel, 1989). Calf-thymus (CT-DNA) was purchased from Bangalore Genei, Bangalore, India. The metal precursor, $\left[\mathrm{RuBr}_{3}\left(\mathrm{AsPh}_{3}\right)_{3}\right]$ and the ligand were prepared by literature method (Natarajan et al., 1977; Sampath et al., 2013). Micro analyses (C, H, N $\& S$ ) were performed on a Vario EL III CHNS analyser at STIC, Cochin University of Science and Technology, Kerala, India. IR spectra were recorded as $\mathrm{KBr}$ pellets in the $400-4000 \mathrm{~cm}^{-1}$ region using a Perkin Elmer FT-IR 8000 spectrophotometer. Electronic spectra were recorded in DMSO solution with a Systronics double beam UV-vis spectrophotometer 2202 in the range 200-800 $\mathrm{nm}$. Magnetic susceptibility measurements of the complexes were recorded using Guoy balance. EPR 
spectra were recorded on a varian E-112 ESR spectrophotometer at $\mathrm{X}$ - band microwave frequencies for powdered samples at room temperature. EI mass spectra of the complexes were recorded on a JEOL GCMATE II mass spectrometer. Melting points were recorded with Veego VMP-DS heating table and are uncorrected.

\subsection{Synthesis of ruthenium(iii) thiosemicarbazone complex, [rubr $\left.2\left(\operatorname{asph}_{3}\right)_{2} l\right]$}

A methanolic solution $(20 \mathrm{~mL})$ containing thiosemicarbazone ligand $(0.110 \mathrm{~g}, 0.5 \mathrm{mmol})$ was added to $\left[\mathrm{RuBr}_{3}\left(\mathrm{AsPh}_{3}\right)_{3}\right](0.630 \mathrm{~g}, 0.5 \mathrm{mmol})$ in benzene $(20 \mathrm{~mL})$. The resulting solution was refluxed for $8 \mathrm{~h}$. The reaction mixture was then cooled to room temperature, which results in the formation of precipitate. It was filtered off and the purity of the complex was checked by TLC. This solid was recrystallized from $\mathrm{CH}_{2} \mathrm{Cl}_{2}$ /Hexane mixture. Our sincere effort to obtain single crystal of the complex went unsuccessful. Yield: $57 \%$. M.P: $268{ }^{\circ} \mathrm{C}$. Anal. calcd. for $\mathrm{C}_{45} \mathrm{H}_{39} \mathrm{As}_{2} \mathrm{Br}_{2} \mathrm{ClN}_{3} \mathrm{RuS}(\%)$ : C, 49.13; H, 3.57; N, 3.82; S, 2.91. Found (\%): C, 49.41; H, 3.88; N, 4.15; $\mathrm{S}, 2.17$. EI-MS: Found $m / z=1100.18\left(\mathrm{M}^{+}\right)$(calculated $\mathrm{m} / z=1100.05$ for $\left.\mathrm{M}^{+}\right) . \quad$ IR $\left(\mathrm{KBr}, \mathrm{cm}^{-1}\right): 1571$ $v(\mathrm{C}=\mathrm{N}) ; 750 \quad v(\mathrm{C}-\mathrm{S}) ; 548 v(\mathrm{Ru}-\mathrm{N}) ; 1439 v(\mathrm{Ru}-$ triphenylarsine). UV-vis (DMSO), $\lambda \max (\mathrm{nm}): 315$, 365 (ILCT), 415 (LMCT). EPR (300 K, 'g' value): 2.14 . $\mu_{\text {eff }}(300 \mathrm{~K}): 1.65 \mu_{\mathrm{B}}$.

\subsection{DNA binding - Titration experiments}

All the experiments involving the binding of complex with CT-DNA were carried out in a doubly distilled water buffer with tris(hydroxymethyl)aminomethane (Tris, $5 \mathrm{mM}$ ) and sodium chloride (50 $\mathrm{mM}$ ) and adjusted to $\mathrm{pH} 7.2$ with hydrochloric acid. A solution of CT-DNA in the buffer gave a ratio of UV absorbance of about 1.8-1.9 at 260 and $280 \mathrm{~nm}$, indicating that the DNA was sufficiently free of protein. The CT-DNA concentration per nucleotide was determined spectrophotometrically by employing an extinction coefficient of $6600 \mathrm{M}^{-1} \mathrm{~cm}^{-1}$ at $260 \mathrm{~nm}$. The complex was dissolved in a mixed solvent of $5 \%$ DMSO and $95 \%$ Tris-HCl buffer. Stock solution was stored at $4{ }^{\circ} \mathrm{C}$ and used within 4 days. Absorption titration experiments were performed with fixed concentrations of the complex $(25 \mu \mathrm{M})$ with varying concentration of DNA (0-50 $\mu \mathrm{M})$. While measuring the absorption spectra, an equal amount of DNA was added to both the test solution and the reference solution to eliminate the absorbance of DNA itself.

\subsection{Cytotoxic study}

\subsubsection{Antibacterial activity}

The in vitro antibacterial screenings of the complex was tested for their effect on certain human pathogenic bacteria by disc diffusion method. The complex was stored dry at room temperature and dissolved in dimethyl sulfoxide. The bacteria (Escherichia coli and Staphylococcus aureus) was grown in nutrient agar medium and incubated at 37 ${ }^{\circ} \mathrm{C}$ for $24 \mathrm{~h}$ followed by frequent subculture to fresh medium, and was used as test bacteria. Then the petriplates were inoculated with a loop full of bacterial culture and spread throughout the petriplates uniformly with a sterile glass spreader. To each disc the test sample and reference antiobiotic (Cotrimazole) were added with a sterile micropipette. The plates were then incubated at 35 ${ }^{\circ} \mathrm{C}$ for $24 \mathrm{~h}$ and at $2{ }^{\circ} \mathrm{o}$ for bacteria. Plates with disc containing respective solvents served as control. Inhibition was recorded by measuring the diameter of the inhibitory zone after the period of incubation.

\section{RESULTS AND DISCUSSION}

Analytical and spectroscopic data for the complex indicate a 1:1 metal-ligand stoichiometry for the complex. The synthetic route of the complex and the proposed structure of the complex are shown in Scheme 1. The complex is soluble in most common organic solvents like $\mathrm{CH}_{2} \mathrm{Cl}_{2}, \mathrm{CHCl}_{3}, \mathrm{DMF}$, DMSO, etc.

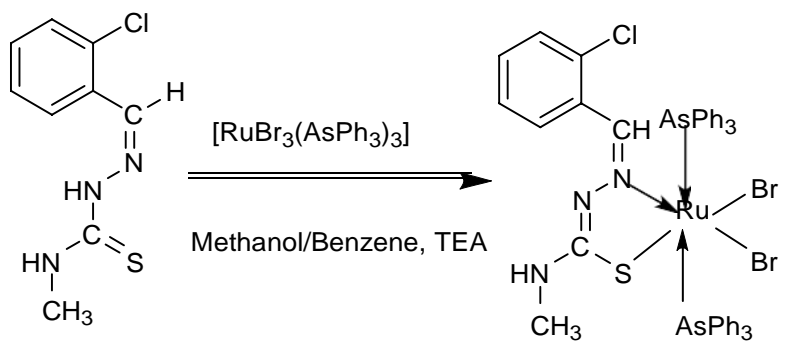

Scheme 1-Synthetic route of the ruthenium(III) thiosemicarbazone complex

\subsection{Infrared spectra}

The complex shows absorption at $1571 \mathrm{~cm}^{-1}$ assigned to azomethine $\mathrm{C}=\mathrm{N}$ which is lower wavelength compared to ligand $\left(1614 \mathrm{~cm}^{-1}\right)$. This is due to the interaction of ligand with metal ion and confirms the coordination through $\mathrm{N}$ atom (Raja and Ramesh, 2010). A band at $851 \mathrm{~cm}^{-1}$ for the ligand due to the vibration of $\mathrm{C}=\mathrm{S}$ double bond was disappeared in the spectrum of the complex and a new band, $\mathrm{C}-\mathrm{S}$ appeared at $750 \mathrm{~cm}^{-1}$ indicating that the other coordination is through thiolate sulphur after enolization followed by deprotonation on sulphur (Thangadurai and Natarajan, 2001). The complex 
shows bands at $548 \mathrm{~cm}^{-1}$ is attributed to $\mathrm{Ru}-\mathrm{N}$ (Manivannam et al., 2007). Moreover, the characteristic absorption band due to triphenylarsine was also observed for all the complexes at $1439 \mathrm{~cm}^{-1}$.

\subsection{Electronic spectra}

The electronic spectrum of the complex (Fig. 1) was recorded in DMSO. The intense bands were observed at 315 and $365 \mathrm{~nm}$ are characterized as ligand centered transitions, $\pi-\pi^{*}$ and $n-\pi^{*}$ transitions, occurring within the ligand orbitals (Sharma et al., 1980). The ground state of ruthenium(III) ( $\mathrm{t}^{5}{ }_{2 \mathrm{~g}}$ configuration) is ${ }^{2} \mathrm{~T}_{2} \mathrm{~g}$, while the first excited doublet levels in the order of increasing energy are ${ }^{2} \mathrm{~A}_{2} \mathrm{~g}$ and ${ }^{2} \mathrm{~T}_{1} \mathrm{~g}$, which arise from $\mathrm{t}_{2 \mathrm{~g}}{ }^{4} \mathrm{e}_{\mathrm{g}}{ }^{1}$ configuration. Since in a $\mathrm{d}^{5}$ system, and especially in ruthenium(III) that has relatively high oxidising properties, the charge transfer bands of the type $\mathrm{L}_{\pi \mathrm{y}} \rightarrow \mathrm{t}_{2 \mathrm{~g}}$ are prominent in the low energy region obscuring the weaker bands due to $d-d$ transition. Therefore, it becomes difficult to assign conclusively the bands of ruthenium(III) complexes appearing in the visible region. Hence, the band that appear at $415 \mathrm{~nm}$ have been assigned to charge transfer transitions, which are in conformity with the assignments made for similar ruthenium(III) complexes (Raja and Ramesh, 2010; Sampath et al., 2013).

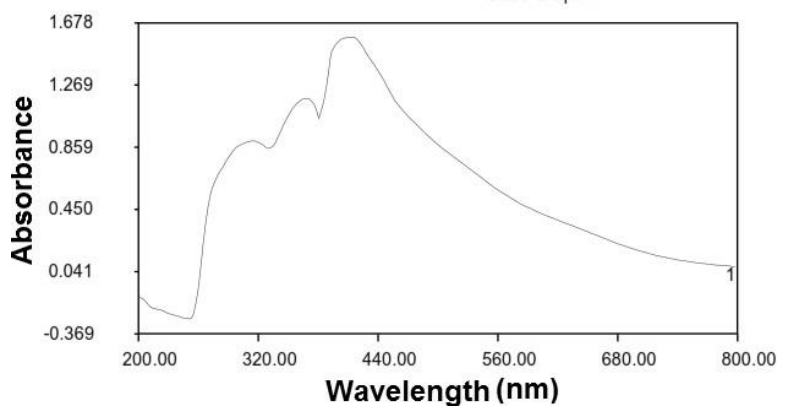

\section{ig. 1. UV-visible spectrum of the complex.}

\subsection{Magnetic moment and EPR spectra}

The room temperature magnetic susceptibility measurements of the ruthenium(III) complex shows that it is paramagnetic. The magnetic moment value, $\mu_{\mathrm{B}}=1.65$ corresponds to single unpaired electron in a low-spin $4 d^{5}$ configuration and confirms that ruthenium is in +3 oxidation state in the complex (Manivannan et al., 2007).

The complexes is uniformly paramagnetic with magnetic moments corresponding to one unpaired electron at room temperature (low-spin $\mathrm{Ru}(\mathrm{III}), \mathrm{t}_{2 \mathrm{~g}}{ }^{5}$ ). The X-band EPR spectrum of powdered sample of the complex was recorded at room temperature and the EPR spectrum of the complex is shown in Fig. 2. The nature of the spectrum revealed the absence of any hyperfine splitting due to interactions with any other nuclei present in the complex. The complex exhibits a single isotropic resonance with $g$ values at 2.14. Although the complex have some distortion in their octahedral geometry, the observation of isotropic line in the EPR spectrum may be due to the occupancy of the unpaired electron in a degenerate orbital (Khan et al., 1990). The nature of spectrum obtained is in good agreement with that of previously reported ruthenium(III) complexes (Khan et al., 1990; Sampath et al., 2013).

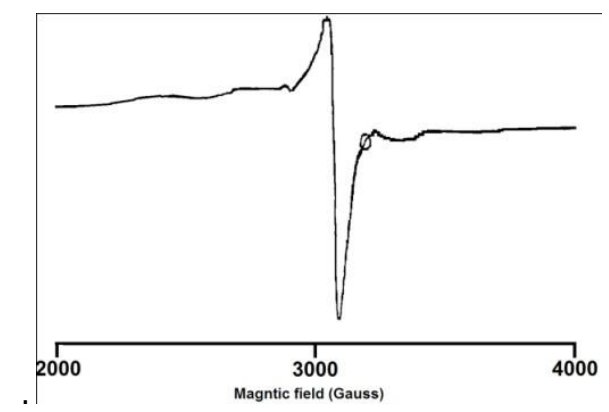

Fig. 2. ESR spectrum of the complex.

\subsection{Mass spectral analysis}

The mass spectrum of the ruthenium(III) complex is in good agreement with the proposed molecular structure. The molecular ion peak, $\left[\mathrm{M}^{+}\right]$ appears at $m / z=1100.48$ confirm the stoichiometry of the complex.

\subsection{DNA binding - Titration experiments}

In the present investigation the binding of the complex has been characterized classically through absorption spectral titrations by following the changes in absorbance and shift in the wavelength as a function of added concentration of DNA. The results of absorption spectra of the complex in the absence and presence of CT-DNA are given in Fig. 3 . As shown in Fig. 3, when titrated with CT-DNA the absorption bands of the complex exhibited hypochromism of $17.55 \%$ with red shifts of $2 \mathrm{~nm}$ at $358 \mathrm{~nm}$. This result suggested an intercalate binding of complex with DNA helix. After the complex intercalate to the base pairs of DNA, the $\pi^{*}$ orbital of the intercalated complexes could couple with $\pi$ orbitals of the base pairs, thus decreasing the $\pi \rightarrow \pi^{*}$ transition energies, hence resulting in hypochromism (Raja et al., 2011). In order to compare quantitatively the binding strength of the complex, the intrinsic binding constants $\left(K_{\mathrm{b}}\right)$ of them with CT-DNA was determined from the following equation. 
$[\mathrm{DNA}] /\left(\varepsilon_{\mathrm{a}}-\varepsilon_{\mathrm{f}}\right)=[\mathrm{DNA}] /\left(\varepsilon_{\mathrm{b}}-\varepsilon_{\mathrm{f}}\right)+1 / K_{\mathrm{b}}\left(\varepsilon_{\mathrm{b}}-\varepsilon_{\mathrm{f}}\right)$

where [DNA] is the concentration of DNA in base pairs and the apparent absorption coefficient $\varepsilon_{\mathrm{a}}, \varepsilon_{\mathrm{f}}$ and $\varepsilon$ correspohd to $A$ obs [ complex], the extinction coefficient of the free complex and the extinction coefficient of the complex when fully bound to DNA, respectively. The plot of [DNA] $/\left(\varepsilon_{\mathrm{a}}-\varepsilon_{\mathrm{f}}\right)$ versus [DNA] gave a slope and the intercept which are equal to $1 /\left(\varepsilon_{\mathrm{b}}-\varepsilon_{\mathrm{f}}\right)$ and $1 / K_{\mathrm{b}}\left(\varepsilon_{\mathrm{b}}-\varepsilon_{\mathrm{f}}\right)$, respectively; $K_{\mathrm{b}}$ is the ratio of the slope to the intercept. The magnitudes of intrinsic binding constant $\left(K_{\mathrm{b}}\right)$ was calculated to be $2.5 \times 10^{4} \mathrm{M}^{-1}$. The observed value of $K_{\mathrm{b}}$ revealed that the ruthenium(III) complex bind strongly than the ligand $\left(1.7 \times 10^{4} \mathrm{M}^{-1}\right)$ to DNA via intercalative mode.

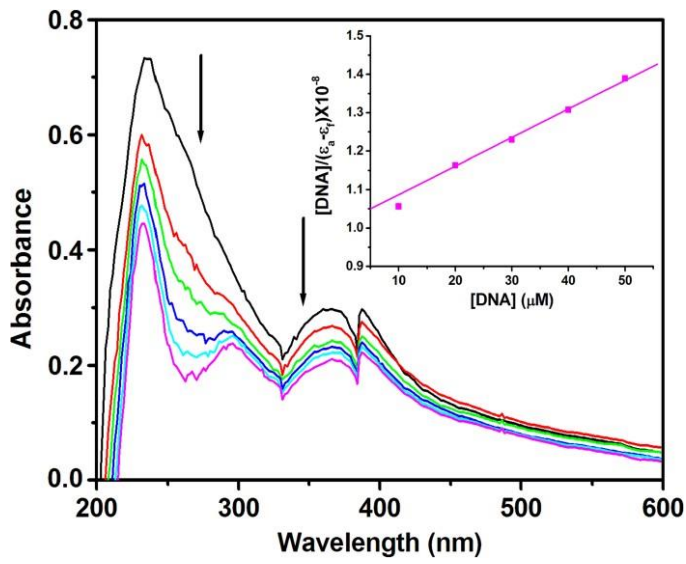

Fig. 3. Electronic spectra of complex in Tris-HCl buffer upon addition of CT-DNA. [Complex] = 25 $\mu M,[D N A]=0-50 \mu M$. Arrow shows the absorption intensities decrease upon increasing DNA concentrations (Inset: Plot between [DNA] and [DNA] $\left./\left[\varepsilon_{\mathrm{a}}-\varepsilon_{\mathrm{f}}\right] \times \mathbf{1 0}^{-8}\right)$.

\subsection{Cytotoxic activity}

\subsubsection{Antibacterial activity}

The antibacterial activity of the complex was tested against the human pathogens (Escherichia coli and Staphylococcus aureus). The screening data are reported in Table 1 . The inhibition activity of ruthenium complex against the bacteria suggesting that chelation facilitates the ability of a complex to cross a cell membrane which leads alteration in the cell permeability and subsequent injury to the cell membrane (Perez et al., 1990; Leelavathy et al., 2009). Moreover, the mode of action of the complex may involve the hydrogen bond through $>\mathrm{C}=\mathrm{N}$ group with active centers of all cell constituents resulting in interference with normal cell process (Thangadurai and Natarajan, 2001). Even though the complex possess significant activity they could not reach the effectiveness of standard drug Cotrimazole.
Table 1. Antibacterial activity of the ligands and complexes.

\begin{tabular}{llc}
\hline \multirow{2}{*}{ Complex } & \multicolumn{2}{c}{$\begin{array}{c}\text { Diameter of inhibition zone } \\
\text { (mm) }\end{array}$} \\
\cline { 2 - 3 } & \multicolumn{2}{c}{ E. coli } \\
\hline $\left.\mathrm{RuBr}_{2}\left(\mathrm{AsPh}_{3}\right)_{2} \mathrm{~L}\right]$ & 17 & 19 \\
Ciprofloxacine & 23 & 26 \\
\hline DMSO & No activity \\
\hline
\end{tabular}

aValues are an average of triplicate runs.

\section{CONCLUSION}

The present contribution describes the synthesis of new ruthenium(III) complex comprising mixture of ligands and, were characterized by various spectroscopic techniques. An octahedral geometry has been tentatively assigned for the complex. The DNA binding ability of the complex assessed by absorption spectroscopy suggested an intercalative mode of binding with binding constant $2.5 \times 10^{5} \mathrm{M}^{-1}$. The complex possesses significant antibacterial activity against panel of bacteria. At this juncture, it is notable to mention that the major chemical and biological findings of this study throw some light on the potential of this complex in a reasonable range of concentrations under in vitro conditions.

\section{REFERENCES}

Ang, W.H. and P.J. Dyson. (2006). Eur. J. Inorg. Chem. 4003-4018.

Friedman, A.E., C.V. Kumar, N.J. Turro and J.K. Barton. (1991). Nucleic Acids Res. 19: 2595-2602.

Hartinger, C.G. S. Zorbas-Seifried, M.A. Jakupec, B. Kynast, H. Zorbas and B.K. Keppler. (2006). Inorg. Biochem. 100: 891-904.

Khan, M.M.T., D. Srinivas, R.I. Kureshy and N.H. Khan. (1990). Inorg. Chem. 29: 2320-2326.

Kostova, I. (2006). Curr. Med. Chem. 13: 1085-1107.

Leelavathy, L., S. Anbu, M. Kandaswamy, N. Karthikeyan and N. Mohan. (2009). Polyhedron 28: 903-910.

Manivannan, S., R. Prabhakaran, K.P. Balasubramanian, V. Dhanabal, R. Karvembu, V. Chinnusamy and K. Natarajan. (2007). Appl. Organometal. Chem. 21: 952-957.

Murugkar A., B. Unnikrishnan, S. Padhye, R. Bhonde, S. Teat, E. Triantafillou and E. Sinn. (1999). Met. Based Drugs 6: 177-182.

Natarajan, K., R.K. Poddar and U. Agarwala. (1977). J. Inorg. Nucl. Chem. 39: 431-435. 
Perez, Z., M. Pauli and P. Bezerque. (1990). Acta Biol. Med. Exp. 15: 113-115.

Pyle, A.M., T. Morii and J.K. Barton. (1990). J. Am. Chem. Soc. 112: 9432-9434.

Rademaker-Lakhai, J.M. D. Van Den Bongard, D. Pluim, J.H. Beijnen and J.H.M. Schellens. (2004). Clin. Cancer Res. 10: 3717-3727.

Raja, D.S., N.S.P. Bhuvanesh and K. Natarajan. (2011). Eur. J. Med. Chem. 46: 4584-4594.

Raja, N. and R. Ramesh. (2010). Spectrochim. Acta A 75: 713-718.

Ronconi, L. and P.J. Sadler. (2007). Coord. Chem. Rev. 25: $1633-1648$.
Sampath, K., S. Sathiyaraj and C. Jayabalakrishnan. (2013). J. Mol. Struct. 1046: 82-91.

Sharma, R.K., R.V. Singh and J.P.J. Tandon. (1980). Inorg. Nucl. Chem. 42: 1382-1384.

Thangadurai, T.D. and K. Natarajan. (2001). Transition Met. Chem. 26: 717-722.

Vogel, A.I. (1989). Textbook of Practical Organic Chemistry. Longman, London.

Yan, Y.K., M. Melchart, A. Habtemariam and P.J. Sadler. (2005). Chem. Commun. 4764-4776. 